\title{
Volatile compounds and palynological analysis from pollen pots of stingless bees from the mid-north region of Brazil
}

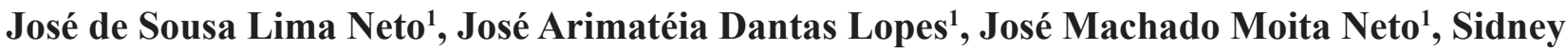 \\ Gonçalo de Lima ${ }^{1}$, Cynthia Fernandes Pinto da Luz ${ }^{2}$, Antônia Maria das Graças Lopes Citó ${ }^{*}$
}

\begin{abstract}
${ }^{1}$ Department of Chemistry, Nature Science Center, Federal University of Piauí, Teresina, PI, Brazil, ${ }^{2}$ Institute of Botany, Center of Research in Vascular Plants, Palynological Research Center, São Paulo, SP, Brazil
\end{abstract}

\begin{abstract}
Samburá is the botanical pollen nectar agglutinated by salivary secretions of bees. Stingless bee pollen samples were collected in three periods of the year in Monsenhor Gil town, PI, Brazil, for extraction of volatile constituents by different techniques, analyzed by gas chromatography-mass spectrometry (GC-MS) and the palynological analysis used to identify the dominant pollen. Among the volatile compounds identified, kaur-16-ene, methyl and ethyl hexadecanoate, methyl linoleate and heneicosane were identified more frequently in the studied parameters: period of sample collection and extraction techniques used. The palynological analysis identified the pollen of Mimosa caesalpiniifolia Benth. as the dominant pollen in all samples studied.
\end{abstract}

Uniterms: Pollen/Scaptotrigona sp. Mimosa caesalpiniifolia Benth. Pollen/volatile constituents. Chromatography-mass spectrometry. Palinology.

\section{INTRODUCTION}

Pollen of stingless bees (also known as Samburá) (Brasil, 2001) consists of botanic pollen combined with nectar and salivary secretions (Dermardersian, Beuther, 2005) and it is collected by worker bees from a variety of plant species. Pollen is the main protein source to bees, for the development of larva (Somerville, 2001), tissues formation (in all bees), to the ovarian development of the queen bee, and the use of which is useful for the increase of the bee community in a beehive (Human et al., 2007; Zerbo, Moraes, Brochetto-Braga, 2001).

The chemical composition of pollen is diverse, it is mainly composed by vitamins, minerals, enzymes, free amino acids, crude proteins, carbohydrates, fatty acids and polyphenolic compounds (Dermardersian, Beuther, 2005; Somerville, 2001; Almeida-Muradian et al., 2005).

Commercially bee pollen is considered a supplement (Kroyer, Hegedus, 2001) however the scientific literature describes some pharmacological properties and therapeutics: antitumor activity (Yang et al., 2007); immunomodulatory

\footnotetext{
*Correspondence: A. M. L. G. Citó. Departamento de Química. Universidade Federal do Piauí. Campus Ministro Petrônio Portela. 64049-550 - Teresina - PI, Brasil. E-mail: gracacito@gmail.com
}

action; antioxidant activity (Carpes et al., 2008; Leja et al., 2007); antianemic action; treatment of respiratory tract infections, endocrine disorders, enteritis, colitis and constipation; poor appetite, decreased blood pressure and prevention of prostate inflammations (Ioirich, 1986).

The aim of this research was to identify, by gas chromatography coupled with mass spectrometry (GC-MS), the volatile constituents of the bee pollen of the genus Scaptotrigona sp. (stingless bees) obtained by different extraction techniques and collected at different periods of the year in a microregion of Piauí State, Brazil, and their botanical origin were identified through palynological analysis.

\section{MATERIAL AND METHODS}

\section{Pollen samples}

The samples of stingless bee pollen were collected manually in pollen pots of hives from Cocal community, in Monsenhor Gil town, Piauí State, Brazil. The collections were made during December 2006 (PAS-1), March (PAS-2) and July (PAS-3), which were located via Global Positioning System (GPS). Coordinates of sampling points: $-5^{\circ} 42^{\prime} 16.64$ ' $\mathrm{S}$ and $-42^{\circ} 38^{\prime} 29.02^{\prime}$ ' W. 


\section{Extration of volatiles oils}

\section{Microhydrodistillation (MD)}

About $10 \mathrm{~g}$ of bee pollen were subjected by microhydrodistillation during 3 hours. Afterwards, the volatile constituents were extracted from hidrolate (mixture of water and volatile oil) by dichloromethane HPLC grade partition $(3 \times 15 \mathrm{~mL})$. The organic phase was dried with anhydrous $\mathrm{Na}_{2} \mathrm{SO}_{4}$ P.A, filtered and concentrated (Torres et al., 2008). The product containing the volatile constituents was kept under refrigeration until analysis GC-MS.

\section{Dynamic headspace (HS)}

Approximately $10 \mathrm{~g}$ of bee pollen was placed in a modified Kitasato flask (with two side outputs). The extraction of volatile constituents from the matrix was done through air suction, which previously passed through a glass tube $10 \mathrm{~cm}$ in length and $0.6 \mathrm{~mm}$ thick filled with a silica column $(6 \mathrm{~cm})$ and activated charcoal $(2 \mathrm{~cm})$ and in the outlet a small glass tube $(5 \mathrm{~cm})$ containing $150 \mathrm{mg}$ of Porapak-Q ${ }^{\circledR}$ was placed. Both glass tubes contained cotton in its extremities, treated with acetone HPLC grade. Subsequently, the volatile constituents were desorbed with double distilled $\mathrm{CH}_{2} \mathrm{Cl}_{2}$ P.A (3 mL) and subjected to $\mathrm{GC}$ MS analysis (Andrade et al., 2007).

\section{Ultrasound-Assisted extraction (US)}

In a $150 \mathrm{~mL}$ Erlenmeyer flask $10 \mathrm{~g}$ of pollen was placed, then $11 \mathrm{~mL}$ of water was added, and also $1.5 \mathrm{~g}$ of magnesium sulfate P.A, $15 \mathrm{~mL}$ of $n$-pentane /ethyl ether 1:2 (both HPLC grade). Then this mixture was put to be extracted in an ultrasonic bath for 30 minutes. Afterwards, the mixture was transferred to a separation funnel, $10 \mathrm{~mL}$ of saturated solution of sodium chloride P.A and $15 \mathrm{~mL}$ of solvent ( $n$-pentane/ethyl ether) were added. The mixture was centrifuged at $3000 \mathrm{rpm}$ for five minutes and the organic phase was collected and concentrated. The volatile constituents were kept under refrigeration until analysis (Alissandrakis et al., 2003).

\section{Solid phase micro extraction (SPME)}

The $5 \mathrm{~g}$ pollen was conditioned in a proper glass flask closed with rubber septum at room temperature for 1 hour. The SPME fiber (Sulpeco Co. Belfone, PA) was coated with 30 microns of polydimethylsiloxane (PDMS) and it was inserted via the septum in the internal space of the flask becoming exposed the matrix (pollen) for 24 hours. After this time, it was inserted into the injector of the gas chromatograph coupled with the mass spectrometer for 1 minute at $240{ }^{\circ} \mathrm{C}$ for the complete desorption of volatiles (Pontes, Marques, Câmara, 2007).
Analysis by Gas Chromatography Coupled with Mass Spectrometry (GC-MS)

After methylation with diazomethane, the identification of volatile constituents was made by GC-MS, on a Shimadzu mass spectrometer model QP5050A equipped with a DB-5 HT column (95\% of polymethylsiloxane and $5 \%$ of phenyl, $30 \mathrm{~m}$ long, $0.25 \mathrm{~mm}$ internal diameter, 0.1 microns thick of the stationary phase film). The temperature setting used was the following: injector at $220^{\circ} \mathrm{C}$, detector at $240{ }^{\circ} \mathrm{C}$ column $60{ }^{\circ} \mathrm{C}$ at 240 ${ }^{\circ} \mathrm{C}$, with heating rate of $3{ }^{\circ} \mathrm{C} \mathrm{min}$. . The carrier gas selected

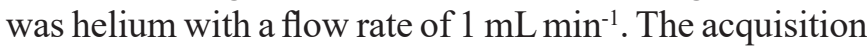
of mass spectrum was done in the rage 40-650 Daltons by the method of electron impact ionization, with ionization energy of $70 \mathrm{eV}$ and ion source at $200^{\circ} \mathrm{C}$. The mass spectra were compared to the entries from the electronic library Wiley229 to then be identified; Kovats indices were also calculated, it was based on retention times of hydrocarbon standards $\left(\mathrm{C}_{10}-\mathrm{C}_{25}\right)$ counterparts injected under the same conditions of the samples, to compare with literature data (Adams, 2007). All analyses were performed in duplicate.

\section{Palynological analysis}

The pollen samples PAS-1, PAS-2 and PAS-3 were identified at the Institute of Botany of São Paulo. For the palynological preparation of microscope slides $2 \mathrm{~g}$ of each pollen sample of stingless bees were withdrawn, and then homogenized separately in $10 \mathrm{~mL}$ of alcohol at $70 \%$. Basically, the pollen preparation of the samples followed the standard European method (Maurizio, Louveaux, 1965) which consists of washing the material with distilled water and glycerin-water followed by centrifugation. The identification of pollen types was based mainly on the reference collection of microscope slides with pollen from the Palynological Research Center of the Institute of Botany of São Paulo, and also in palynological catalogs. Approximately 500 pollen grains per sample were identified for the class percentage definitions of dominant pollen ( $\mathrm{D}>45 \%$ ), accessory pollen ( $\mathrm{A}<45$ to $15 \%$ ), isolate pollen $(\mathrm{I}<15$ to $3 \%)$ and occasional pollen $(\mathrm{O}<3 \%)$ (Barth, 1989).

\section{Statistical analysis}

Statistical analyses were performed using the IBM ${ }^{\circledR}$ SPSS $®$ Statistics software version 21.0. The peak area (percentage) of identified volatile compounds obtained was compared according to the extraction method and period of collection of samples of pollen. Differences between them were established using one-way analysis of 
variance (ANOVA) followed by Tukey's test. Differences at the $5 \%$ level of significance $(\mathrm{p}<.05)$ were considered statistically significant.

\section{RESULTS AND DISCUSSION}

Along the gathering of pollen samples there was a variation in the amount collected in each period. In December about $180 \mathrm{~g}$ of pollen of native bees was obtained, March and July for about $360 \mathrm{~g}$ and $1180 \mathrm{~g}$ were obtained respectively. Overall this research identified 138 substances (Table I).

The major class of compounds identified were hydrocarbons and esters followed by terpenoids, ketones

TABLE I - Chemical constituents of volatile stingless bee pollen collected in the months of December, March and July and extracted by HS, MD, US and SPME with their relative abundances

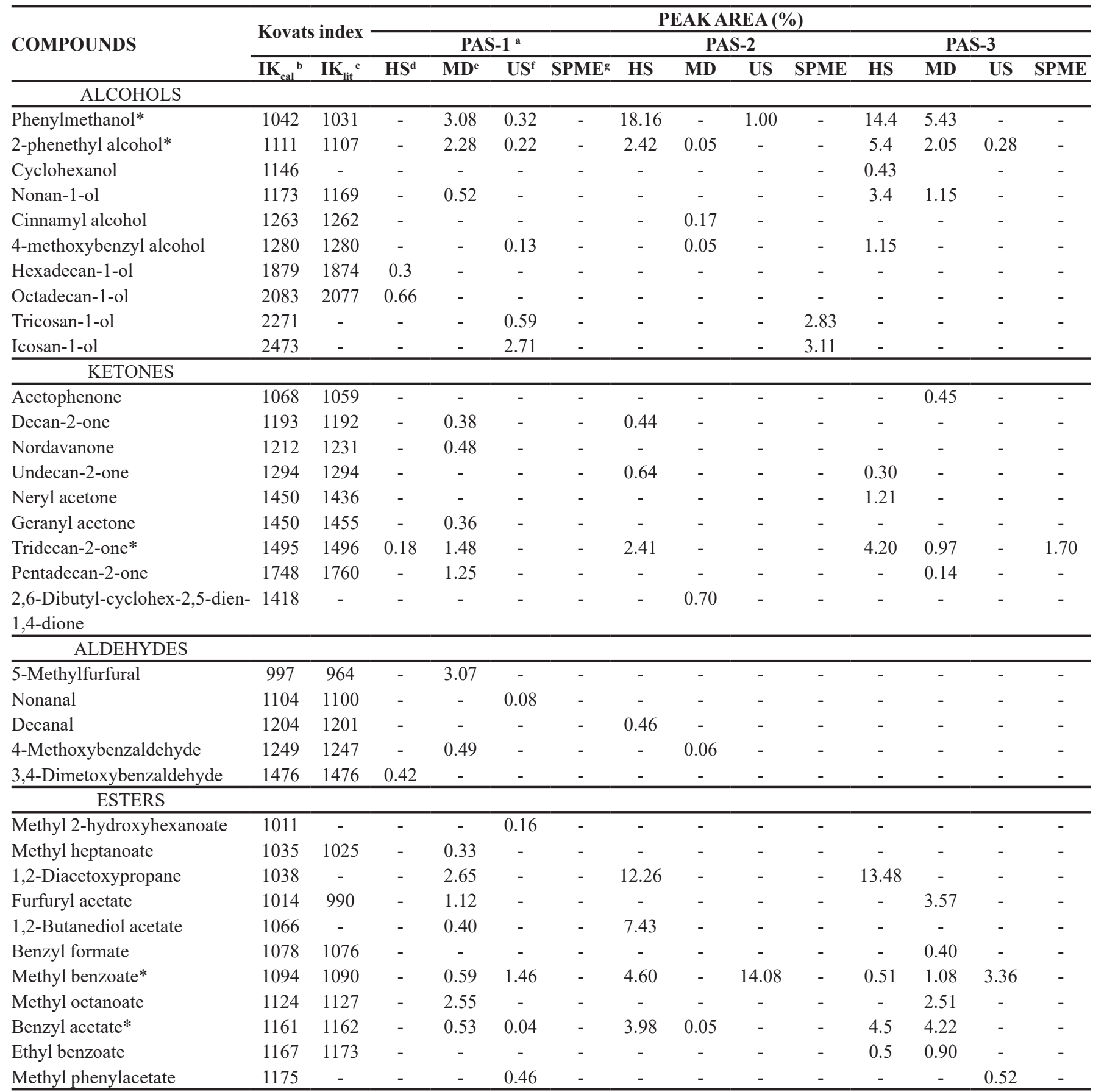


TABLE I - Chemical constituents of volatile stingless bee pollen collected in the months of December, March and July and extracted by HS, MD, US and SPME with their relative abundances (cont.)

\begin{tabular}{|c|c|c|c|c|c|c|c|c|c|c|c|c|c|c|}
\hline \multirow{2}{*}{ COMPOUNDS } & \multirow{2}{*}{\multicolumn{2}{|c|}{ Kovats index }} & \multicolumn{12}{|c|}{ PEAKAREA (\%) } \\
\hline & & & \multicolumn{4}{|c|}{ PAS-1 ${ }^{a}$} & \multicolumn{4}{|c|}{ PAS-2 } & \multicolumn{4}{|c|}{ PAS-3 } \\
\hline Ethyl octanoate & 1199 & 1197 & - & - & - & - & - & - & - & - & 0.38 & 0.36 & - & - \\
\hline Ethyl phenylacetate $*$ & 1253 & 1258 & - & 0.74 & - & - & 1.16 & 0.08 & - & - & 2.88 & 2.17 & - & - \\
\hline Methyl hydrocinnamate* & 1270 & - & - & - & 0.15 & - & 1.25 & - & 7.53 & - & 0.42 & 0.24 & 1.00 & - \\
\hline (E)-Methyl deca-7,9-dienoate & 1310 & - & - & 2.26 & - & - & - & - & - & - & - & - & - & - \\
\hline Nonanyl acetate & 1313 & 1312 & - & - & - & - & - & - & - & - & 5.2 & 2.02 & - & 1.52 \\
\hline Methyl decanoate & 1325 & 1325 & - & 1.72 & - & - & 0.31 & - & - & - & 0.26 & 0.50 & - & - \\
\hline Ethyl hydrocinnamate & 1344 & - & - & - & - & - & 0.51 & 0.11 & - & - & 2.51 & 2.84 & - & - \\
\hline $\begin{array}{l}\text { Methyl 2-hydroxy-3- } \\
\text { phenylpropanoate }\end{array}$ & 1361 & - & - & - & 0.37 & - & - & - & - & - & - & - & - & - \\
\hline 4-Methoxybenzyl acetate & 1414 & 1413 & - & - & - & - & 0.37 & - & - & - & 0.59 & - & - & - \\
\hline (E)-Cinnamyl acetate & 1440 & 1446 & - & - & - & - & - & - & - & - & - & 0.26 & - & - \\
\hline (E)-Ethyl cinnamate & 1458 & 1467 & - & - & - & - & - & - & - & - & 0.47 & 0.69 & - & - \\
\hline$\delta$-Decalactone & 1488 & 1494 & - & 0.56 & - & - & - & - & - & - & - & 0.53 & - & - \\
\hline Methyl dodecanoate & 1525 & 1525 & 0.20 & 2.52 & - & - & 0.29 & - & - & - & - & 0.15 & - & - \\
\hline Methyl 3,4-dimethoxybenzoate & 1589 & - & - & - & 0.07 & - & - & - & - & - & - & - & - & - \\
\hline Ethyl dodecanoate & 1595 & 1595 & - & - & - & - & - & - & - & - & - & 0.13 & - & - \\
\hline Methyl tetradecanoate & 1725 & 1723 & 2.36 & 3.19 & 0.09 & - & 1.15 & - & - & - & 0.40 & 0.31 & - & - \\
\hline Benzyl benzoate & 1748 & 1760 & - & - & - & - & - & - & - & - & - & 0.14 & - & - \\
\hline $\begin{array}{l}\text { Methyl 12-methyl } \\
\text { tetradecanoate }\end{array}$ & 1795 & - & 0.37 & - & - & - & - & - & - & - & - & - & - & - \\
\hline $\begin{array}{l}\text { Methyl 14-methyl- } \\
\text { hexadecanoate }\end{array}$ & 2027 & - & 1.12 & - & - & - & - & - & - & - & - & - & - & - \\
\hline Methyl linoleate* & 2090 & 2085 & 1.37 & 5.42 & 25.00 & - & 0.69 & - & 9.23 & - & - & 0.66 & 9.31 & - \\
\hline Methyl linolenate & 2096 & - & - & 1.67 & 12.30 & - & - & - & 9.67 & - & - & - & 6.90 & - \\
\hline Methyl octadec-9-enoate & 2100 & - & 16.28 & - & - & - & 2.74 & - & - & - & - & - & - & - \\
\hline Methyl octadecanoate * & 2129 & 2125 & 7.69 & 0.73 & 1.8 & - & 3.61 & - & - & - & 1.70 & 0.19 & 0.42 & - \\
\hline 2-Ethylhexyl & 2156 & - & 0.73 & - & - & - & - & - & - & - & - & - & - & - \\
\hline 4-methoxycinnamate & & & & & & & & & & & & & & \\
\hline Ethyl linoleate* & 2159 & - & 0.59 & 2.28 & 0.34 & 7.30 & - & - & - & 1.92 & 0.60 & 11.91 & 6.86 & 5.9 \\
\hline Ethyl linolenate & 2165 & - & - & - & - & - & - & - & - & - & - & 3.54 & 4.29 & 6.13 \\
\hline Ethyl octadec-9-enoate & 2166 & - & 1.31 & - & - & - & - & - & - & - & - & - & - & - \\
\hline Ethyl octadecanoate & 2196 & 2196 & 0.35 & - & 0.11 & - & - & - & - & - & - & - & 0.20 & - \\
\hline Methyl nonadecanoate & 2228 & - & 0.16 & - & - & - & - & - & - & - & - & - & - & - \\
\hline Methyl eicosanoate & 2329 & - & 0.3 & - & 2.04 & - & - & - & - & - & - & - & - & - \\
\hline Dioctyl hexanedioate & 2397 & - & 0.98 & - & - & - & - & - & - & - & - & - & - & - \\
\hline Methyl tricosanoate & 2619 & - & 0.26 & - & 0.5 & - & - & - & - & - & - & - & - & - \\
\hline Methyl tetracosanoate & 2709 & - & 0.48 & - & 2.22 & - & - & - & - & - & - & - & 0.35 & - \\
\hline
\end{tabular}


TABLE I - Chemical constituents of volatile stingless bee pollen collected in the months of December, March and July and extracted by HS, MD, US and SPME with their relative abundances (cont.)

\begin{tabular}{|c|c|c|c|c|c|c|c|c|c|c|c|c|c|c|}
\hline \multirow{3}{*}{ COMPOUNDS } & \multirow{2}{*}{\multicolumn{2}{|c|}{ Kovats index }} & \multicolumn{12}{|c|}{ PEAK AREA (\%) } \\
\hline & & & \multicolumn{4}{|c|}{ PAS-1 ${ }^{\text {a }}$} & \multicolumn{4}{|c|}{ PAS-2 } & \multicolumn{4}{|c|}{ PAS-3 } \\
\hline & $I K_{\mathrm{cal}}^{\mathrm{b}}$ & $I K_{\mathrm{lit}}{ }^{\mathrm{c}}$ & $\mathbf{H S}^{\mathrm{d}}$ & $\mathbf{M D}^{\mathbf{e}}$ & $\mathbf{U S}^{\mathrm{f}}$ & SPME $^{g}$ & HS & MD & US & SPME & HS & MD & $\mathbf{U S}$ & SPME \\
\hline \multicolumn{15}{|l|}{ HYDROCARBONS } \\
\hline$n$-Undecane & 1100 & 1100 & - & - & 0.14 & - & - & - & 1.05 & - & - & - & 0.25 & - \\
\hline$n$-Dodecane & 1200 & 1200 & - & - & 0.25 & - & - & - & - & - & - & - & 0.72 & - \\
\hline$n$-Tridecane & 1300 & 1300 & - & - & - & - & - & - & - & - & - & - & 0.66 & - \\
\hline Tetradec-1-ene & 1354 & 1389 & - & - & - & - & - & 0.15 & - & - & - & - & - & - \\
\hline$n$-Tetradecane & 1401 & 1400 & 0.11 & - & 0.04 & - & - & - & - & - & 0.8 & - & - & - \\
\hline$n$-Pentadecane & 1500 & 1500 & 0.23 & - & - & - & 0.89 & - & - & - & 1.05 & - & - & - \\
\hline Hexadec-1-ene & 1550 & 1589 & - & - & - & - & - & 0.49 & - & - & - & - & - & - \\
\hline$n$-Hexadecane & 1600 & 1600 & 0.34 & - & - & - & 0.72 & - & - & - & 1.00 & - & - & - \\
\hline Heptadec-8-ene & 1675 & 1675 & - & - & - & - & 0.42 & - & - & - & 0.95 & - & - & 1.87 \\
\hline$n$-Heptadecane & 1700 & 1700 & 0.93 & - & - & - & 0.87 & - & - & - & 0.6 & - & - & - \\
\hline$n$-Octadecane & 1800 & 1800 & 1.08 & - & - & - & 0.70 & - & - & - & 0.42 & - & - & - \\
\hline 2.6.10.14- & 1810 & - & 0.86 & - & - & - & - & - & - & - & - & - & - & - \\
\hline \multicolumn{15}{|l|}{ Tetramethylhexadecane } \\
\hline Nonadec-1-ene & 1871 & - & 0.45 & 0.22 & - & - & - & - & - & - & - & - & - & - \\
\hline Eicos-9-ene & 1872 & - & - & 0.47 & - & - & - & - & 1.71 & - & - & - & - & - \\
\hline n-Nonadecane & 1900 & 1900 & - & 1.69 & - & - & 1.36 & - & - & - & - & 0.43 & - & 1.37 \\
\hline n-Eicosane & 2000 & 2000 & 0.98 & - & 0.05 & - & - & - & - & - & - & - & - & 3.45 \\
\hline n-Heneicosane* & 2101 & 2100 & - & 2.2 & - & - & 1.12 & - & 4.00 & 29.89 & 0.30 & 1.14 & 3.60 & 2.32 \\
\hline n-Docosane* & 2200 & 2201 & 1.06 & - & 0.23 & - & - & - & - & 1.34 & - & - & 0.23 & 3.25 \\
\hline n-Tricosane* & 2301 & 2300 & - & 1.68 & 3.15 & - & 0.46 & - & 4.52 & 25.09 & - & 0.75 & 6.10 & 2.30 \\
\hline 7-Hexyldocosane & 2373 & - & - & - & 0.18 & - & - & - & - & - & - & - & - & - \\
\hline n-Tetracosane & 2400 & 2400 & 1.44 & - & 0.35 & - & - & - & - & - & - & - & - & 3.23 \\
\hline n-Pentacosane* & 2502 & 2500 & 1.62 & 0.49 & 6.59 & - & - & - & 5.59 & 2.88 & - & 0.29 & 9.70 & 2.32 \\
\hline Cyclopentacosane & 2658 & - & - & - & - & - & - & - & - & - & - & - & 8.5 & - \\
\hline 11-Decyl-tetracosane & 2682 & - & - & - & - & - & - & - & - & - & - & - & 3.60 & - \\
\hline \multicolumn{15}{|l|}{ TERPENOIDS } \\
\hline (Z)-Linalool oxide & 1075 & 1072 & - & 1.28 & - & - & - & - & - & - & - & 1.88 & - & - \\
\hline (E)- Linalool oxide & 1090 & 1086 & - & 0.75 & - & - & - & - & - & - & - & 1.00 & - & - \\
\hline Nerol oxide & 1152 & 1158 & - & - & - & - & - & - & - & - & - & 0.69 & - & - \\
\hline Pyranoid linalool oxide & 1165 & 1176 & - & - & - & - & 0.83 & - & - & - & - & - & - & - \\
\hline$\alpha$-Terpineol & 1150 & - & - & - & - & - & - & 0.07 & - & - & - & - & - & - \\
\hline Terpendiol & 1190 & - & - & - & 0.06 & - & 1.24 & - & - & - & 1.6 & - & 0.88 & - \\
\hline Carvacrol & 1302 & 1299 & 0.17 & - & - & - & - & - & - & - & - & - & - & - \\
\hline$\alpha$-Copaene & 1368 & 1376 & - & - & - & - & - & - & - & - & 0.31 & - & - & - \\
\hline$\beta$-Caryophyllene & 1408 & 1419 & - & - & - & - & - & - & - & - & 0.34 & - & - & - \\
\hline$\alpha$-Bergamotene & 1430 & 1434 & - & - & - & - & - & - & - & - & 0.21 & - & - & - \\
\hline$\alpha$-Farnesene & 1506 & 1505 & - & 0.47 & - & - & - & - & - & - & - & - & - & - \\
\hline$\delta$-Cadinene & 1515 & 1523 & - & - & - & - & - & - & - & - & 0.32 & - & - & - \\
\hline (E)- Nerolidol & 1560 & 1563 & - & 0.22 & - & - & - & - & - & - & - & - & - & - \\
\hline Dendrolasin & 1574 & 1571 & - & - & - & - & - & - & - & - & - & - & - & 3.92 \\
\hline$(Z, Z)$ - Farnesol & 1675 & 1698 & 1.81 & - & - & - & - & - & - & - & - & - & - & - \\
\hline$(E, Z)$-Farnesol & 1717 & 1715 & - & 1.15 & - & - & - & - & - & - & - & - & - & - \\
\hline Rimuene & 1888 & 1896 & 0.33 & - & - & - & - & - & - & - & 0.22 & - & - & - \\
\hline Kaur-15-ene & 1961 & 1997 & - & - & - & - & - & - & - & - & - & 0.26 & - & - \\
\hline Kaur-16-ene* & 2005 & 2043 & 1.50 & 4.12 & 0.45 & 13.86 & 4.67 & - & 2.05 & 22.14 & 5.9 & 4.60 & 2.6 & 22.1 \\
\hline Squalene & 2785 & - & 20.21 & - & 1.20 & - & - & - & - & - & - & - & 1.09 & 22.45 \\
\hline \multicolumn{15}{|l|}{ OTHERS } \\
\hline Phenol & 1007 & - & - & - & - & - & 3.86 & - & - & - & - & - & - & - \\
\hline
\end{tabular}


TABLE I - Chemical constituents of volatile stingless bee pollen collected in the months of December, March and July and extracted by HS, MD, US and SPME with their relative abundances (cont.)

\begin{tabular}{|c|c|c|c|c|c|c|c|c|c|c|c|c|c|c|}
\hline \multirow[b]{2}{*}{ COMPOUNDS } & \multirow{2}{*}{\multicolumn{2}{|c|}{ Kovats index }} & \multicolumn{12}{|c|}{ PEAK AREA (\%) } \\
\hline & & & \multicolumn{4}{|c|}{ PAS-1 ${ }^{\text {a }}$} & \multicolumn{4}{|c|}{ PAS-2 } & \multicolumn{4}{|c|}{ PAS-3 } \\
\hline$\overline{p \text {-Cresol }}$ & 1079 & 1076 & - & 1.04 & 0.05 & - & - & - & - & - & - & - & - & - \\
\hline Hotrienol & 1104 & - & - & 4.25 & - & - & - & - & - & - & 8.9 & 5.34 & - & - \\
\hline$\overline{\text { Glycerol }}$ & 1117 & 950 & - & - & - & - & - & - & - & - & - & - & 2.28 & - \\
\hline Benzoic acid & 1161 & & - & - & - & - & - & 0.19 & - & - & - & - & - & - \\
\hline $\begin{array}{l}\text { Cyclopentadiene-N- } \\
\text { methylamine }\end{array}$ & 1222 & - & - & - & - & - & - & 0.38 & - & - & - & - & - & - \\
\hline Butylated hydroxytoluene & 1475 & 1514 & - & - & - & - & - & 96.69 & - & - & - & - & - & - \\
\hline Hexadecanoic acid & 1961 & 1959 & - & - & - & 4.46 & - & - & - & 4.76 & - & - & - & 1.81 \\
\hline
\end{tabular}

UNIDENTIFIED

COMPOUNDS (SUM)

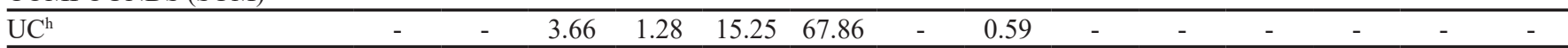

aPAS - volatile oil in stingless bee pollen; ${ }^{\mathrm{b}} \mathrm{IK}$ cal - calculated Kovats index of substances detected; ${ }^{\mathrm{c}} \mathrm{IK}$ lit - index of Kovats found in the literature of the substances detected; ${ }^{\mathrm{HS}}$ - extraction by headspace; ${ }^{\mathrm{M} D}$ - extraction by mycrohydrodistillation; ${ }^{\mathrm{f} U S}$ - extraction assisted by ultrasound; ${ }^{g}$ SPME - extraction by solid phase microextraction; hUC - unidentified compounds; $(*)$ - Nineteen substances most frequently among all the substances identified.

and alcohols. Through statistical tests (ANOVA and Independent T-test), using the null hypothesis less than $0.05(\mathrm{p}<0.05)$, there was a significant difference between the type of extraction technique (HS and SPME) in the obtainment of the volatile compounds, but this didn't happen between collection seasons (PAS-1, 2 and 3 ). Analyzing the number and relative abundance of compounds identified, the HS technique had more compounds than SPME. It happened because SPME extracts the volatile compounds of samples by adsorption, a passive process, while other extraction processes (HS, MD and US) use assets mechanisms.

The literature of the volatile compounds of stingless bees pollen is scarce, therefore, in order to evidence the source of compounds identified they were compared with compounds indentified in the stingless bees. These bees prepare bee pollen using their bodies and mandibles, mixing secretions (cuticular, cephalic and glandulars) with botanic pollen and the compounds present in secretions and its bodies are purchased for others nestmates as chemical signals, essential for the hive. Age, castes selection, recruitment for several jobs, invaders, predators and nestmates are determined by chemical communication and feed as the bee pollen is a way to transmit the chemical signals. (Pianaro et al., 2009). In several studies there was the predominance of hydrocarbons and esters in stingless bee secretions as in our study (Francke et al., 2000; Gracioli-Vitti et al., 2004; Engels et al., 1987; Engels et al., 1993; Cruz-Lopes, Patrício, Morgan, 2001; Abdalla et al., 2004). The comparison of the volatile compounds identified from the pollen samples with the literature, showed that forty-one volatile compounds were identified from the cephalic part and from mandibular and accessory glands from stingless bees. Nineteen compounds most common in the pollen of stingless bees studied, five are common to the literature (methyl hexadecanoate, heneicosane, ethyl linoleate, tricosane and methyl otcadecanoate) and more related to stingless bees.

Bees of Melipona genus use cuticular hydrocarbons to recognize nestmates and invaders (Pianaro et al., 2007). Nanotrigona and Plebleia genus use abdominais secretions for differentiate its species and castes. Workes and males of Plebeia droryana excret in abdominal extracts tetradecanal and many quantiftit of fatty acids, like linolenic and linoleic acids, respectvely (Pianaro et al., 2009). But another study indicated that hidrocarbons and estheres are the majoritary in cephalic glands of Scaptotrigona postica and perfom the comunication in hive (Engels et al., 1993).

Seven compounds (methyl linoleate, methyl cinnamate, benzyl acetate, methyl benzoate, methyl hidrocinnamate, ethyl phenylacetate and kaur-16-ene) are not common to the studies of cephalic parts or glandular secretion of stingless bees. These seven compounds are more related to the flora of the region, because shikimate and essential fatty acids derivatives are biosynthesized in plants not in animals (Dewick, 2009). Other studies about 
TABLE II - Main pollen types identified in three samples of stingless bee pollen of the genus Scaptotrigona sp. from Monsenhor Gil, Piaui, Brazil, collected at December 2006 (PAS-1), March 2006 (PAS-2) and July 2006 (PAS-3)

\begin{tabular}{lccc}
\hline Percentage class of the pollen type & \multicolumn{3}{c}{ Frequencies (\%) of the pollen types } \\
\cline { 2 - 4 } & PAS-1 & PAS-2 & PAS-3 \\
\hline $\begin{array}{l}\text { Dominant pollen } \\
\quad \text { Mimosa caesalpiniifolia } \text { Benth. }\end{array}$ & 77.85 & 53.3 & 77.0 \\
$\begin{array}{l}\text { Accessory pollen } \\
\quad \text { Piptadenia } \text { sp. }\end{array}$ & - & 25.3 & - \\
Isolate pollen & & & \\
$\quad$ Piptadenia sp. & 8.7 & - & 10.4 \\
$\quad$ Myrcia sp. & 7.5 & - & - \\
$\quad$ Acacia sp. & - & 5.3 & - \\
$\quad$ Copaifera $s p$. & - & - & 4 \\
\hline
\end{tabular}

attracting foraging bees demonstrated that the presence of fatty acids odor was an important chemical signal for bees choose a botanic pollen as nutritional supply (Pernal, Currie, 2002; Starratt, Boch, 1971).

According to the palynological analysis the Mimosa caesalpiniifolia Benth. was the dominant pollen, frequently found in Monsenhor Gil (Santos et al., 2008) and presented frequency of $77.8 \% 53 \%$ and $77 \%$ respectively for the samples PAS-1, PAS-2 and PAS-3. This species is a native tree of the Brazilian cerrado and also known as unhade-gato or sabiá (Pio Corrêa, 1984). Other significant pollen types were Piptadenia sp., Copaifera sp., Acacia sp. and Myrcia sp., which the Piptadenia sp. pollen was considered an accessory pollen at the percentage classes whereas the others were considered as isolate pollen (Figure 1 and Table II).

The Mimosa caesalpiniifolia Benth. was a plant frequently visited by these bees. Melissopalynological studies observe the Mimosa caesalpiniifolia Benth. as an important trophic resource for bees to collect pollen, due to high nutritional value of this pollen type and as it is a typical plant of the mid-north region of Brazil (Barth, Dutra, Justo, 1999; Sodre et al., 2008; Luz, Thomé, Barth, 2007; Melo et al., 2009). However, in the collection site, this plant and others weren't preserved, due to the presence of many agricultural areas and were constantly burned, common practice in Brazilian cerrado (Ikeda et al., 2008) directly affecting the survival of stingless bees.

\section{CONCLUSION}

The palynological analysis demonstrated that the dominant pollen type was from the native tree Mimosa caesalpiniifolia Benth. The bee pollen of the genus

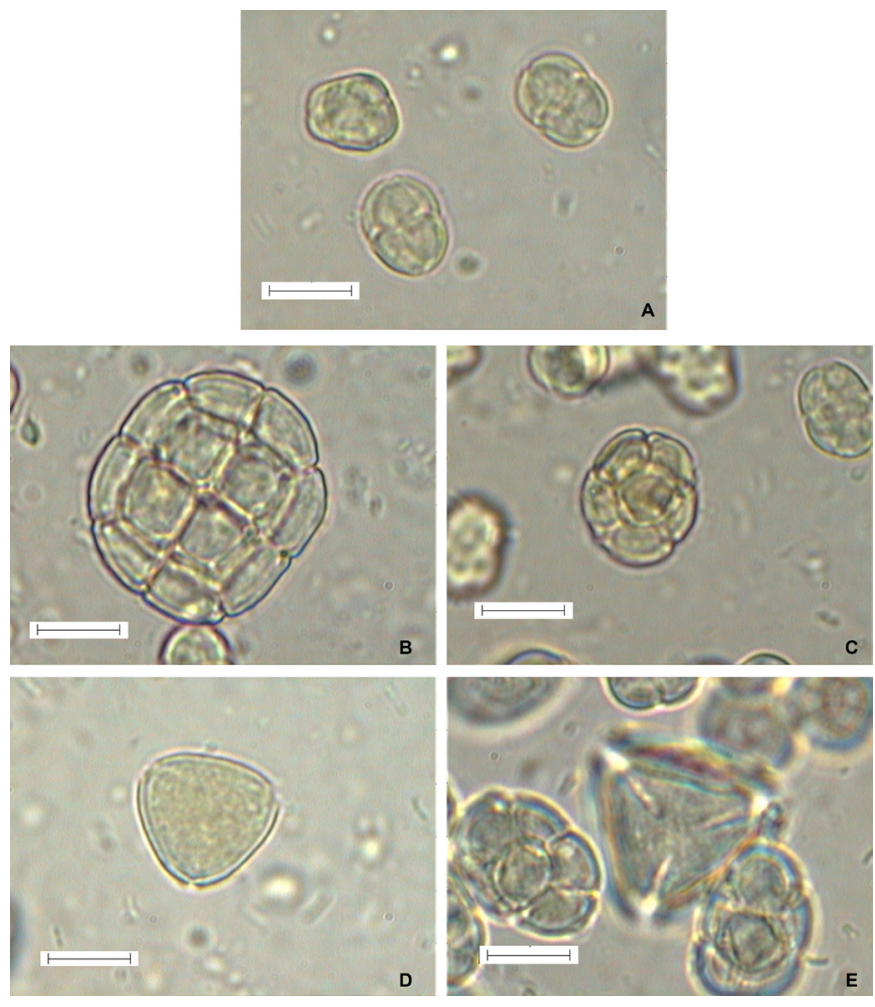

FIGURE 1 - Photographs of pollen grains obtained from optical microscope of the main pollen types identified in samples of stingless bee pollen of Monsenhor Gil-PI, BRA. A - Mimosa caesalpiniifolia Benth; B-Acacia sp.; C-Piptadenia sp.; $D$-Myrcia sp.; E-Copaifera sp. surrounded by Piptadenia sp.

Scaptotrigona sp. from Monsenhor Gil-PI demonstrated a diversified volatile chemical composition.

\section{ACKNOWLEDGMENTS}

This study was supported by grants from CAPES 
for the scholarship awarded to the Master J. S. Lima Neto; LAPETRO for the use of GC/MS; UFPI and Institute of Botany of São Paulo for the palynological analysis. The authors also extend their thanks to the Conselho Nacional de Desenvolvimento Científico e Tecnológico (CNPq) for the fellowship of 'Productivity in research' to C. F. P. da Luz.

\section{REFERENCES}

ABDALLA, F.C.; JONES, G.R.; MORGAN, D.; CRUZLANDIM, C. Chemical composition of the dufour gland secretion in queens of Melipona bicolor (Hymenoptera, Meliponini). J. Braz. Chem. Soc., v.15, n.5, p.621-5, 2004.

ADAMS, R.P. Identification of essential components by gas chromatography/mass spectroscopy. 4.ed. Illinois: Allured Publishing Corporation, 2007.

ALISSANDRAKIS, E.; DAFERERA, D.; TARANTILIS, P.A.; POLISSIOU, M.; HARIZANIS, P.C. Ultrasound-assisted extraction of volatile compounds from citrus flowers and citrus honey. Food Chem., v.82, n.4, p.575-82, 2003.

ALMEIDA-MURADIAN, L.B.; PAMPLONA, L.C.; COIMBRA, S.; BARTH, O.M. Chemical composition and botanical evaluation of dried bee pollen pellets. J. Food Compos. Anal., v.18, n.1, p.105-11, 2005.

ANDRADE, M.S.; SAMPAIO, T.S.; NOGUEIRA, P.C.L.; RIBEIRO, A.S.; BITTRICH, V.; AMARAL, M.C.E. Volatile compounds from leaves and flowers of Garcinia macrophylla. Chem. Nat. Compd., v.43, n.2, p.221-4, 2007.

BARTH, O.M. O pólen no mel brasileiro. Rio de Janeiro: Luxor, 1989. 150p.

BARTH, O.M.; DUTRA, V.M.L.; JUSTO, R.L. Análise polínica de algumas amostras de própolis do Brasil meridional. Ciênc. Rural, v.29, n.4, p.663-7, 1999.

BRASIL. Instrução Normativa nº. 3, de 19 de Janeiro 2001. Regulamentos técnicos de identidade e qualidade de apitoxina, cera de abelha, geléia real, geleia real liofilizada, pólen apícola, própolis e extrato de própolis. Diário Oficial da União, Seção 1, 23 jan. 2001.

CARPES, S.T.; PRADO, A.; MORENO, I.A.M.; MOURÃO, G.B.; ALENCAR, S.M.; MASSON, M.L. Avaliação do potencial antioxidante do pólen apícola produzido na região sul do Brasil. Quim Nova., v.31, n.7, p. 1660-4, 2008.
CRUZ-LÓPEZ, L.; PATRICIO, E.F.L.R.A.; MORGAN, E.D. Secretions of stingless bees: The Dufour gland of Nannotrigona testaceicornis. J. Chem. Ecol., v.27, n.1, p.69-80, 2001.

DERMARDEROSIAN, A.; BEUTHER, J.A. Review of natural products: facts and comparisons. 4.ed. St Louis: Wolters Kluwer Health Inc., 2005. 1343p.

DEWICK PM. Medicinal natural products: a biosynthetic approach. 3.ed. Chichester: John Wiley \& Sons Ltd, 2009. 539 p.

ENGELS, E.; ENGELS, W.; SCHRÖDER, W.; FRANCKE, W. Intranidal worker reactions to volatile compounds identified from cephalic secretions in the stingless bee, Scaptotrigona postica (Hymenoptera, Meliponinae). J. Chem. Ecol., v.13, n.2, p.371-86, 1987.

ENGELS, E.; ENGELS, W.; LÜBKE, G.; SCHRODER, W.; FRANCKE, W. Age-related patterns of volatile cephalic constituents in queens of the neotropical stingless bee Scaptotrigona postica Latr (Hymenoptera, Apidae). Apidologie, v.24, n.6, p.539-48, 1993.

FRANCKE, W.; LÜBKE, G.; SCHRÖDER, W.; RECKZIEGEL, A.; IMPERATRIZ-FONSECA, V.; KLEINERT, A.; ENGELS, E.; HARTFELDER, K.; RADTKE, R.; ENGELS, W. Identification of oxygen containing volatiles in cephalic secretions of workers of brazilian stingless bees. J. Braz. Chem. Soc., v.11, n.6, p.562-71, 2000.

GRACIOLI-VITTI, L.F.; ABDALLA, F.C.; MORAES, R.L.M.S.; JONES, G.R. The chemical composition of the mandibular gland secretion of Melipona bicolor Lepeletier, 1836 (Hymenoptera, Apidae, Meliponini): a comparative study among castes and sexes. J. Braz. Chem. Soc., v.15, n.5, p.777-81, 2004.

HUMAN, H.; NICOLSON, S.W.; STRAUSS, K.; PIRK, C.W.W.; DIETEMANN, V. Influence of pollen quality on ovarian development in honeybee workers (Apis mellifera scutellata). J. Insect. Physiol., v.53, n.7, p.649-55, 2007.

IOIRICH, N.P. As abelhas: farmacêuticas com asas. 2.ed. Moscou: Mir, 1986. 248p.

IKEDA, F.S.; MITJA, D.; VILELA, L.; SILVA, J.C.S. Banco de sementes em cerrado sensu stricto sob queimada e sistemas de cultivo. Pesq. Agropec. Bras., v.43, n.6, p.667-73, 2008. 
KROYER, G.; HEGEDUS, N. Evaluation of bioactive properties of pollen extracts as functional dietary food supplement. Innov. Food Sci. Emerg. Technol., v.2, n.3, p.171-4, 2001.

LEJA, M.; MARECZEK, A.; WYZGOLIK, G.; KLEPACZBANIAK, J.; CZEKOŃSKA, K. Antioxidative properties of bee pollen in selected plant species. Food Chem., v.100, n.1, p.237-40, 2007.

LUZ, C.F.P.; THOMÉ, M.L.; BARTH, O.M. Recursos tróficos de Apis mellifera L. (Hymenoptera, Apidae ) na região de Morro Azul do Tinguá, Estado do Rio de Janeiro. Rev. Bras. Botânica, v.30, n.1, p.29-36, 2007.

MAURIZIO, A.; LOUVEAUX, J. Pollens de plantes melliferes d'Europe. Paris: U.G.A.F, 1965. 148p.

MELO, I.L.P.; FREITAS, A.S.; BARTH, O.M.; ALMEIDAMURADIAN, L.B. Relação entre a composição nutricional e a origem floral de pólen apícola desidratado. Rev. Inst. Adolfo Lutz, v.68, n.3, p.346-53, 2009.

PERNAL, S.F.; CURRIE, R.W. Discrimination and preferences for pollen-based cues by foraging honeybees, Apis melifera L. Anim. Behav., v.63, n.2, p.369-90, 2002.

PIO CORRÊA, M. Dicionário das plantas úteis do Brasil e das exóticas cultivadas. Rio de Janeiro: Imprensa Nacional, 1984. v.6.

PIANARO, A.; FLACH, A.; PATRICIO, E.F.L.R.A.; NOGUEIRA-NETO, P.; MARSAIOLI, A.J. Chemical changes associated with the invasion of a Melipona scutellaris colony by Melipona rufiventris workers. $J$. Chem. Ecol., v.33, n.5, p.971-84, 2007.

PIANARO, A.; MENEZES, C.; KERR, W.E.; SINGER, R.B.; PATRICIO, E.F.L.R.A.; MARSAIOLI, A.J. Stingless bees: Chemical differences and potential functions in Nannotrigona testaceicornis and Plebeia droryana males and workers. J. Chem. Ecol., v.35, n.9, p.1117-28, 2009.
PONTES, M.; MARQUES, J.C.; CÂMARA, J.S. Screening of volatile composition from Portuguese multifloral honeys using headspace solid-phase microextraction-gas chromatography-quadrupole mass spectrometry. Talanta, v.74, n.1, p.91-103, 2007.

SANTOS, L.G.P.; BARROS, R.F.M.; ARAÚJO, J.L.L.; VIEIRA, F.J. Diversity of useful plant resources in the City of Monsenhor Gil. Piauí State. Brazil. Func. Ecosyst. Commun., v.2, p.72-80, 2008.

SODRÉ, G.S.; MARCHINI, L.C.; MORETI, A.C.C.C.; CARVALHO, C.A.L. Tipos polínicos encontrados em amostras de méis de Apis mellifera em Picos, Estado do Piauí. Ciência Rural, v.38, n.3, p.839-42, 2008.

SOMERVILLE, D.C. Nutritional value of bee collected pollens. Report DAN 134A. A report for the Rural Industries Research and Development Corporation. Published NSW Agriculture. Goulburn: NSW, 2001.

STARRATT, A.N.; BOCH, R. Synthesis of the octadecantrans-2, cis-9, cis-12-trienoic acid and its evaluation as a honey bee attractant. Can. J. Biochem. Cell B., v.49, n.2, p.251-54, 1971.

TORRES, R.N.S.; LOPES, J.A.D.; NETO, J.M.M.; CITÓ, A.M.D.G.L. Constituintes voláteis de própolis Piauiense. Quim. Nova, v.31, n.3, p.479-85, 2008.

YANG, X.; GUO, D.; ZHANG, J.; WU, M. Characterization and antitumor activity of pollen polysaccharide. Int. Immunopharmacol., v.7, n.4, p.427-34, 2007.

ZERBO, A.C.; MORAES, R.L.M.S.; BROCHETTOBRAGA, M.R. Protein requirements in larvae and adults of Scaptotrigona postica (Hymenoptera: Apidia, Meliponinae): midgut proteolytic activity and pollen digestion. Comp. Biochem. Physiol. - B Biochem. Mol. Biol., v.129, n.1, p.139-47, 2001.

Received for publication on $03^{\text {rd }}$ June 2014 Accepted for publication on $16^{\text {th }}$ November 2016 